\title{
and Health (ICASSETH 2019) \\ The Society Participation in Eco Farming at Supporting Area of Taman Nasional Gunung Ciremai Kuningan Regency
}

\author{
Yayat Rahmat Hidayat*, Akhmad Jaeroni \\ Agriculture Faculty \\ Universitas Swadaya Gunung Jati \\ Cirebon, Indonesia \\ *yayat.rahmat1982@gmail.com, jaeroniakhmad@gmail.com
}

\begin{abstract}
The existence of the Taman Nasional Gunung Ciremai (TNGC) has the goals to give the benefits for surrounding society both directly and indirectly. There are two benefits provided by TNGC, both ecological and social benefits. Ecologically, the existence of TNGC gives the benefits to contribute ecosystem balances for the sustainability of organism and human beings so that the benefits can be enjoyed by the society around TNGC. Socially, TNGC gives the benefits for the sustainability of society in the area of Mount Ciremai. To create the symbiosis mutualism between the community and TNGC, the activity which aims to improve the ecosystem for the area of Mount Ciremai and the life of society should be conducted. The purpose of this research is to describe society participation in implementing eco farming in the supporting area of the Mount Ciremai National Park that can gives the benefits economically and ecologically. The method of this research is Participatory Action Research (PAR). It is participatory research encouraging the participation of society in implementing eco farming with demplot (demonstration plot) and the practice of the implementation of eco farming. This research was conducted in six months since the planning the activity until making the report of the activity. The findings of this research show that the level of society participation in implementing eco farming is good because the society has adequate information on eco farming and the awareness to implement it.
\end{abstract}

Keywords: eco farming, environmentally friendly, participation

\section{INTRODUCTION}

Taman Nasional Gunung Ciremai (called TNGC) located in West Java has great potential in the balance of the ecosystem because it has many natural resources. Geographically, TNGC is located in Kuningan, Majalengka and Cirebon Districts. The society hasn't used these natural resources maximally either for fulfilling economic needs such as food supply, ecosystems or others.

The existence of Mount Ciremai as a national park cannot be separated from the role of society especially in buffer zone. The role of society to preserve the ecosystem of Mount Ciremai is not maximal. Conceptually, it can break the existence of Mount Ciremai as protected forest. Some works have been done by either the Government through many programs or society.

To maintain the ecosystem balance of Mount Ciremai, there must be an effort to encourage mutual relations between society and the ecosystem of Mount Ciremai. As the realization of mutual relations, society can utilize the existence of ecosystem in Mount Ciremai and they can have preserved it [1]. In fact, TNGC and buffer zone have mutual relation between one component and other components (symbiosis of mutualism). This symbiosis can be in the form of mutually beneficial interaction. Through this symbiosis of mutualism, it is hoped to build the heath of buffer zone so the purpose of managing national park can be achieved through ecosystem balance between the area and buffer zone.

There are 54 villages around TNGC. 31 villages come from Kuningan Regency and 22 villages come from Majalengka Regency, and 1 village comes from Cirebon Regency. Most of the population around TNGC are farmers. 65.476 people $(68,79 \%)$ are farmers in Kuningan Regency, and 16.075 people (34\%) are farmers in Majalengka Regency [2].

One of the strategies to manage Mount Ciremai area is the implementation of health farming based on society. Health farming movement can be realized through the utilization of potential natural resources such as utilizing various microbes that can produce environmentally friendly fertilizer for farmers in buffer zone.

Cibuntu Village has the potential of a goat village as capital to implement environmentally friendly agriculture, namely organic fertilizer manufacturing materials because it has many natural resources with a good ecosystem that can support the realization of health farming. Geographically, Cibuntu village is in buffer zone of TNGC in Kuningan Regency. The ecological potential and the existence of goat villages have not been maximally utilized by society to realize agro-tourism villages that prioritize ecological values. In more detail, some of the problems found in the assisted areas are as follows: The society does not understand the benefits of health farming, the society has not been able to produce organic fertilizer decomposing bacteria, the society has not been formed to drive health farming in Cibuntu Village, Pasawahan District, 
Kuningan Regency, and the society is not maximized in making organic fertilizer based on local potential.

They successfully achieve their economic objective and are capable of implementing technical progress. The introduction of new technologies makes it possible for production capabilities to grow. However, this model of development encounters barriers arising from environmental limitations. Demanding requirements of consumers as to the quality of produced food, as well as protection of natural resources, encourage a perspective of an agricultural holding in terms of its relationships with the environment.

The analysis conducted confirms that the direction of production determined by the holding's agricultural type is the factor with the strongest impact on ecological and economic sustainability of agricultural holdings. Dairy cattle holdings exerted less pressure on the environment due to the largest share of permanent grasslands. However, this direction of production poses threats to the environment due to excessive stocking density. All holding types had unfavorable results in terms of crop structure. This is the effect of excessive simplify cation of the crop structure and elimination of winter crops. Granivores holdings exhibited a greater degree of agroecological sustainability due to soil coverage by vegetation and stocking density. However, while their use of technologies allowed for better economic effects, these technologies also posed a burden to the environment. In the case of field crop holdings, conditions of agro-ecological sustainability were met in terms of soil coverage by vegetation and stocking density. Granivores holdings achieved the best results from the perspective of economic effects. During the years 2011-2012, the income of a family-owned agricultural holding per full-time worker in the family was $37 \%$ greater than in field crop holdings and $57 \%$ greater than in dairy cattle holdings [3].

The Objectives of the Research is describing the development of the implementation of eco farming in the buffer zone of Mount Ciremai National Park, Kuningan Regency. Describing the level of community participation in implementing eco farming in the buffer zone of Mount Ciremai National Park, Kuningan Regency.

\section{Methods}

The method used in this study is Participatory Action Rural (PAR). PAR is an empirical methodological approach in which people directly affected by a problem under investigation engage as core searchers in the research process, which includes action, or intervention, into the problem [4]. It is one of the Participatory Action Research methods for community empowerment. This method is a research strategy that prioritizes community participation, which is carried out from identifying problems, developing programs and planning solutions together.

The writers obtained the data through participant observation, interviews, and survey. Qualitative data were analyzed through assembling the data, coding the data, comparing the data, building interpretations, and reporting outcomes [5]. The actors of empowerment put the society as active subject in implementing activities.
- To Plan. The first activity carried out in this study was to plan the types of activities to be carried out. Planning is carried out jointly between program implementers and the society. Program implementers have many roles as facilitators and mediators to facilitate and motivate target audiences to plan activities. The form of activities is to provide assistance to societies so that they have active participation in realizing health farming in Cibuntu village, forming societies that implement health farming and analyzing local potential as a medium of health farming.

- To Know. After planning the activities, the programs that have been made are socialized so the subjects of the research know them well.

- To Understand. The audience and implementer understand all activities that will be carried out so that the activities can run well.

- To Action. After the activity is designed, known and understood, the implementers and the audience carry out the sequence of activities that have been made.

- Evaluation Program. So that all activities can be carried out and achieved, an evaluation of all stages of the activity is carried out so if some obstacles are found, they will be solved soon by alternative solution.

\section{RESUlTS AND Discussion}

Kuningan Regency is one of the buffer zones of Mount Ciremai National Park which has potential on many natural resources so that regional development is directed to the development of the agricultural sector as its economic base. Some economic sectors that can be developed are eco-tourism, agriculture, fisheries and livestock sectors. In the agricultural sector, Kuningan Regency focused on the development of organic agriculture by utilizing local potential as a support for its production input needs. The basic inputs for farming production are derived from Mount Ciremai such as plantbased fertilizers, decomposing bacteria for the management of organic fertilizer and other potentials that are being tested by government institutions (Mount Ciremai National Park).

The implementation of Eco Farming in Kuningan Regency has progressed significantly. It can be seen from the application of an environmentally friendly agricultural system carried out institutionally such as forming a community that drives environmentally friendly agriculture (health farming). The formation of health farming community Kuningan Regency is caused by the high willingness of the community. The process of forming the institution was carried out by participatory. To encourage the formation of a health farming community, the activities carried out are as follows:

\section{A. Mentoring the Formation of a Health Farming Community in Cibuntu Village, Pasawahan District, Kuningan Regency}

This mentoring is done to invite community participation in implementing health farming community internalization. This internalization is done so that the community has the 
willingness and ability in forming a health farming community. This mentoring is done through a participatory method, or facilitating the process of forming issues from private issues of community members so that it becomes a communal (group) issue. When the communal issue was formed, an agreement was made to form a Health Farming Community (KPS) in Cibuntu Village, Pasawahan District, Kuningan Regency.

\section{B. The Formation of a Health Farming Community in Cibuntu Village, Pasawahan District, Kuningan Regency}

The formation of a Health Farming Community is carried out through a participatory process, especially for two interested groups, namely the food crop farming group and the goat breeders group incorporated in goat village. Goat village is goat breeders group as a side business of Cibuntu Society. Until now the society is not fully aware of utilizing the goat dung especially for making manure to support organic farming (health farming). The total of existing goat dung is very potential to make manure because there are 1000 goats in Cibuntu village.

As an effort to build community participation in implementing agricultural activities in the buffer zone of Mount Ciremai National Park (TNGC) in Kuningan Regency, the main activity is to establish community institutions, namely Health Farming Community (KPS) in Cibuntu Village, Pasawahan District, Kuningan Regency. The process of institutional formation starts from coordinating activities with the government apparatus of Cibuntu Village. Initial coordination is carried out for the socialization of activities to the community as well as a consolidated media for farmers and breeders to develop issues and raise awareness of health farming for the community.

The activity involves several stakeholders, including food crop farming group and the goat breeders group hereinafter referred to as goat village. To build the willingness of society in health farming, internalization process is carried out as an effort to build consolidation and community participation.

Treatment T1 (volatile attractant based on guava) was the most effective in capturing fruit flies [6]. The predominant species of fruit fly was A. oblique. With the attractant juices of guava and orange, the highest capture of the four species of fruit flies was achieved. The hydrolyzed protein showed low efficacy than natural attractants. Although MTD index was low, concerning to the rate needed to control fruit flies, our outcomes permit us to suggest the possibility of using this organic mechanism for fruit fly control in an orange tree, avoiding synthetic pesticides as a hazard for farmers and environment.

After internalizing all interested parties, the community has an awareness of the importance of health farming. Conceptually health farming is an agricultural system that prioritizes local wisdom with the principle of back to nature. The existence of food crop farming group and the goat breeders group can build an organic farming system in Cibuntu Village. These groups agreed on a mutually beneficial collaboration for the implementation of economic activities in food crop farming and animal husbandry. The establishment of this health farming is caused by the availability of local resources, namely the existence of goat dung which is used as material for making manure for rice fields. Meanwhile, with the advancement of agriculture, farmers also get a benefit because they can provide food naturally.

Cultivars Nanung produced the number of tillers per hill, number of productive tillers per hill, and the weight of 1000 grains higher than Pance Kuning cultivars in Gunung Makmur paddy fields. Moreover, Pance Kuning produced the number of tillers per hill, number of productive tillers per hill, the percentage of filled grain per panicle, weight of 1000 grains and potential yield per hectare higher than Nanung in Petung. Nitrogen fertilizer resulted different effects on the number of tillers per hill, the percentage of filled grain per panicle and the weight of 1000 grains. Nanung and Pance Kuning showed a positive response to the application of $75 \mathrm{~kg} \mathrm{~N}$ ha- 1 in Petung for the character of tiller number and weight of 1000 grains [7].

Eco farming which is implemented in Kuningan Regency provides great benefits for the sustainability of the agricultural system and the realization of organic agriculture because the system used in agricultural applications, especially the use of natural materials or organic materials derived from the surrounding ecology.

A research conducted by John explained that we explore the evolutionary nature of interactions between government policy, farm decision-making and ecosystem services in Shucheng County, Anhui Province, 1950-2015 [8]. Analyses of ecological, social and economic trends are complemented by interviews with local farmers. Since the Household Responsibility System started in 1980, there has been a tradeoff between rising levels of provisioning services and falling levels of regulating services with evidence that critical thresholds have been passed for water quality. Using a Framework for Ecosystem Service Provision, we argue that farmers have acted only as ecosystem service providers and have not influenced the policies that have brought about the trade-offs. Over the period, ecological degradation is best described as an example of 'creeping normalcy' where cumulative conventional actions by individual farmers produce unsustainable losses in regulating services. The Chinese government should act to balance the various ecosystem services through valuation and national policy. In this respect, there is a need for agencies that can provide place-based advice to farmers that will allow them to maintain productivity levels while pursuing restorative actions. Even with new policies, the draw of urban employment, high production costs and an ageing population threaten the viability of farming in these marginal agricultural areas.

\section{CONCLUSION}

Based on the research findings above, it can be concluded as follows:

- The formation of Health Farming Community in Cibuntu Village, Pasawahan Sub district, Kuningan District starts from the establishment of community participation in implementing the concept of eco farming for agricultural sustainability in Kuningan Regency through an ecological based agriculture system. 
- The level of community participation is good in the institutional aspects and in the implementation of eco farming so that ecological-based farming systems can work.

- For sustainable implementation of the eco farming system, it is necessary to carry out activities that lead to increase the expertise/capacity of farmers in a health farming system. Some of the activities that need to be carried out are training in making manure and training on organic farming in accordance with the SOP.

- It needs support from other parties such as the village government and local government for the sustainability of eco farming in Cibuntu Village, Pasawahan District, Kuningan Regency.

\section{ACKNOWLEDGMENT}

Thank you for all parties who helped the writers to conduct this research especially for Universitas Swadaya Gunung Jati that financed this research.

\section{REFERENCES}

[1] T. Sambar, "Pengertian Pemberdayaan Masyarakat," unpublished.

[2] A. San, "Pengelolaan Mikroba bermanfaat di Taman Nasional Gunung Ciremai untuk Lingkungan Sehat. Balai TNGC Kuningan," unpublished.

[3] K. Chomentowska, "Specialization and Sustainable Development of Agricultural Holdings," Journal of Agribusiness and Rural Development, vol. 1, pp. 87-93. 2016.

[4] L.F. Rodriguez and T.M. Brown, "From voice to agency: Guiding principles for participatory action research with youth," Wiley InterScience, 2009.

[5] A. Burns, Collaborative Action Research for English Language Teachers. New York.: Cambridge University Press, 1999.

[6] E. Ganchozo-Mendoza, J. Muñoz-Rengifo, R. Villamar-Torres, J Molina-Villamar, L.C.G. Cruzaty, J.A. Intriago-Quintana and S.M Jazayeri, "The Strategy of Organic Pest Control in Ecuador: Capture Effectiveness of Fruit Fly (Anastrepha) Species in Orange Tree Regulated by Volatile Alimentary Attractants," AGRIVITA, Journal of Agricultural Science, vol. 40, no. 3, pp. 472-480, 2018.

[7] M.S. Rusdiaynsyah, "Response of two local Rice cultivar to different doses of nitrogen fertilizer in two paddy fields," Agrivita journal of agricultural science, vol. 39, pp. 137-144, 2017.

[8] J.A. Dearing, K. Zhang, W. Cao, T.P. Dawson, D.A. McKay, P. Sillitoe, and X. Yang, "Who determines the trade-offs between agricultural production and environmental quality? An evolutionary perspective from rural eastern China," International Journal of Agricultural Sustainability, vol. 17, no. 5, pp. 347-366, 2019. 